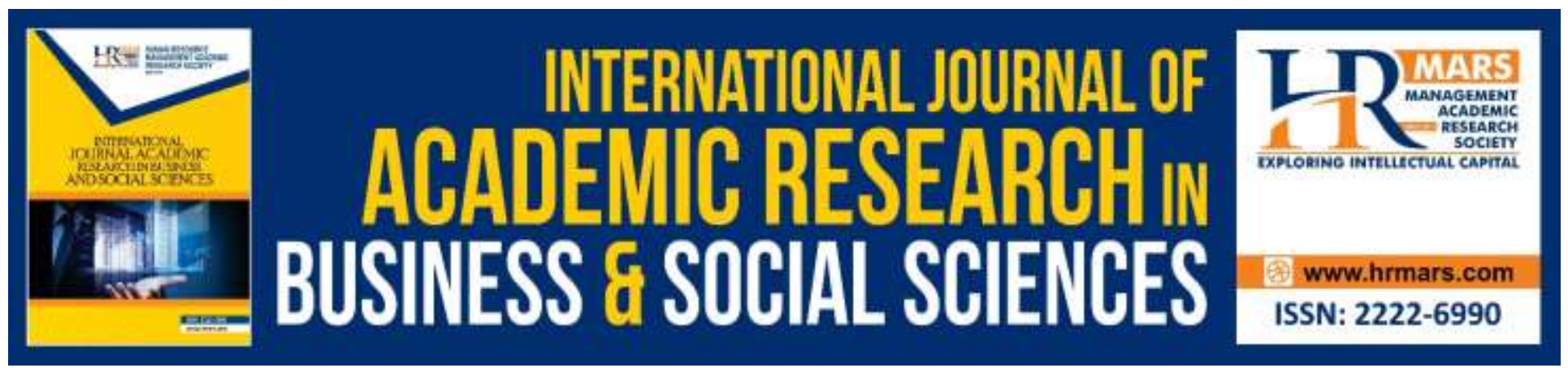

\title{
Self-Efficacy and Language Learning Strategies as Determinants of Students' English Language Proficiency
}

\author{
Mohd Iqbal Ahamat @ Ahamad, Nabilah Abdullah
}

To Link this Article: http://dx.doi.org/10.6007/IJARBSS/v9-i13/6256

DOI: $10.6007 /$ IJARBSS/v9-i13/6256

Received: 12 March 2019, Revised: 17 April 2019, Accepted: 12 June 2019

Published Online: 26 August 2019

In-Text Citation: (Ahamad \& Abdullah, 2019)

To Cite this Article: Ahamad, M. I. A. @, \& Abdullah, N. (2019). Self-Efficacy and Language Learning Strategies as Determinants of Students' English Language Proficiency. International Journal of Academic Research in Business and Social Sciences, 9(13), 206-217.

Copyright: (C) 2019 The Author(s)

Published by Human Resource Management Academic Research Society (www.hrmars.com)

This article is published under the Creative Commons Attribution (CC BY 4.0) license. Anyone may reproduce, distribute, translate and create derivative works of this article (for both commercial and non-commercial purposes), subject to full attribution to the original publication and authors. The full terms of this license may be seen

at: http://creativecommons.org/licences/by/4.0/legalcode

Special Issue: Revolutionizing Education: Challenges, Innovation, Collaboration, 2019, Pg. 206 - 217 http://hrmars.com/index.php/pages/detail/IJARBSS

JOURNAL HOMEPAGE

Full Terms \& Conditions of access and use can be found at http://hrmars.com/index.php/pages/detail/publication-ethics 


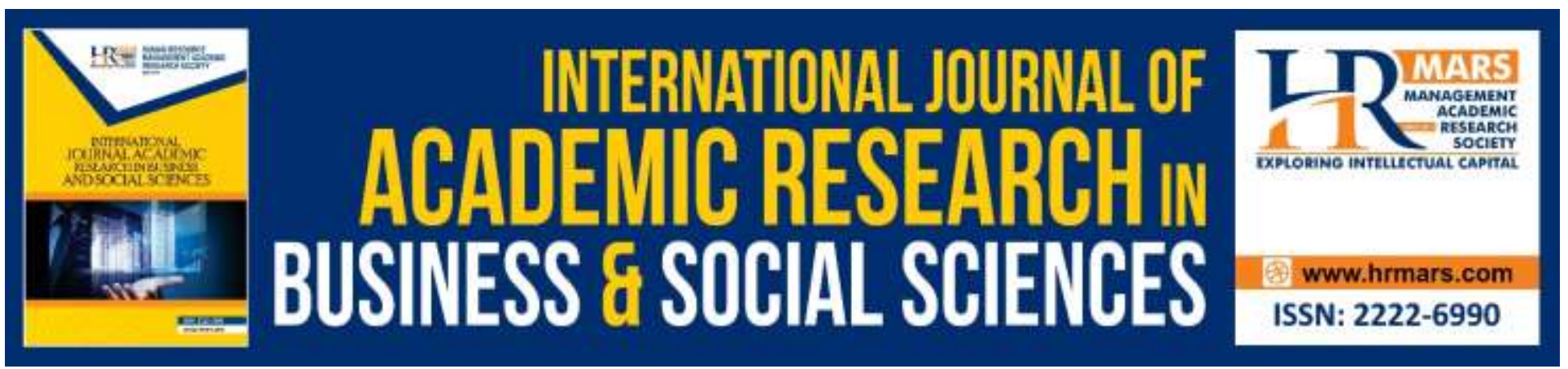

\title{
Self-Efficacy and Language Learning Strategies as Determinants of Students' English Language Proficiency
}

\author{
Mohd Iqbal Ahamat @ Ahamad \\ Universiti Tenaga Nasional, Malaysia \\ Nabilah Abdullah \\ Universiti Teknologi MARA, Malaysia
}

\begin{abstract}
Malaysia was recently ranked among top twelve out of 72 participated countries in the ranking for English language proficiency ${ }^{3}$. Despite the good achievement, English language instructors in Malaysian higher learning institutions still have problems with students' proficiency and involvement in English language classrooms. This study intended to investigate the relationships between self-efficacy belief and language learning strategies, with English language proficiency. The study employed a quantitative research design which involved 341 samples from Universiti Tenaga Nasional (UNITEN) Sultan Haji Ahmad Shah campus. Questionnaires on Self Efficacy Beliefs and Language Learning Strategies were randomly distributed and the result revealed that self-efficacy belief has significant relationship with learners' level of proficiency in English language. However, out of the six language learning strategies, affective strategy was reported not having relationship with students' English language proficiency.
\end{abstract}

Keywords: English Language, Proficiency, Language Learning Strategies, Self-Efficacy

Introduction

In Malaysia, English is considered as a prominent language where it is officially proclaimed as the second language. During the colonial era, English plays a significant part in career development and social mobility (Asmah, 1992, 1995 as cited in Subramaniam, 2003). The advent of Internet has brought English to its upmost position where it is now the language that connects people around the globe. Today, mastering the language has become one of the pre-requisites for employment. As reported in The Star (2016), Datuk Seri Abdul Wahid Omar, the Minister in the Prime Minister's Department has revealed that poor command of the English language is listed as one of the top five reasons of unemployment in Malaysia together with other four other causes, namely unrealistic salary demands, fastidious about the job, lack of communication skills and deficiency in character and 
attitude. This shows that English language should not be taken for granted as it can be an added value for graduates' employment.

Despite Malaysia being ranked twelfth from 72 countries in a recent survey on English language proficiency (EF Education First, 2017), outranked only by Singapore in Asia, studies have revealed that students are passive in the English language classroom (Aini \& Normazla, 2008). Among student behaviors commonly seen include reluctance answering questions in the target language, parroting sentence structures given by teachers, showing signs of disinterest in class, all suggesting lack of competency in the English language. The above findings are further supported by the researcher's personal experience teaching English at a private higher institution the language is not commonly used by students. In fact, most of them are experiencing language anxiety since the tender age of seven. Hazlina (2016) also reported similar case in her observation of new graduates whereby despite outstanding academic performance, they still struggle using the language at the workplace.

The above problem related to English language proficiency may happen due to numerous factors of which the two most influential, and commonly reported, are self-efficacy and language learning strategies. Given the importance to elevate students' English language proficiency, this study aims to further scrutinize students' self-efficacy and language learning strategies if indeed the two stated factors are dominant predictors of English language proficiency.

\section{Literature Review}

Self-efficacy concerns the learners' capabilities or self-belief (Bandura, 2006). Raoofi, Tan and Swee Chan (2012)'s study on Self-efficacy in Second/Foreign Language Learning Contexts proves that selfefficacy is a dominant determinant of students' performance in different language skills and tasks. The other significant factor said to be related to the learners' proficiency is their language learning strategies. Werden and Rubin (1987) defines language learning strategies (LLS) as approaches that learners personally come up with to accommodate their language learning while Oxford (1989) refer the term as "behaviours or actions which learners use to make language learning more successful, self-directed and enjoyable" (p.100). Scarcela and Oxford (2003) provide further elaboration which include particular actions, behaviors, steps or techniques applied by students to improve their language learning.

Studies on self-efficacy in Malaysian language learning context are still limited in numbers. Bandura (1994) who is among the pioneers of the study defined self-efficacy as "people's beliefs about their capabilities to produce designated levels of performance that exercise influence over events that affect their lives" (p.2). It also plays significant roles in determining one's own feeling, thinking, motivation and behavior. Zimmerman and Pons (1986) cited that language learners who regularly employ learning strategies would have high level of self-efficacy. It is believed that language learners who have high self-efficacy belief would use the target language comfortably and regularly than those who have low self-efficacy belief. Wong (2005) reported that students with high writing self-efficacy have the tendency to spend more time on writing task, motivated to earn good grades and willing to try and take risks. Kim and Lorshbach (2005) did a study on pre-university ESL students' self-efficacy and speaking ability in a private university and it was found that high level of self-efficacy was shown 
in students' ability to speak in English. It was also revealed that students with high confidence level performed better than those who have low self-efficacy beliefs.

Past studies have shown there is direct relationship between language learning strategies (LLS) and performance (Woodrow, 2005; Muelas \& Navarro, 2014; Shyr, et al., 2017). Uslu et al. (2016) revealed a prominent finding in their respective research that language learning strategies could significantly determine $20 \%$ of students' achievement that are in support of the previous literatures. Presently, there are numerous studies on language learning strategies in which researchers attempted to define and classify it into distinct categories.

\section{Methodology}

This study employed a correlational research design since its aims was to investigate the relationships between self-efficacy belief and language learning strategies, with English language proficiency. Data was gathered via the use of questionnaire which was divided into three sections. The first section $A$ taps into the demographic profile of the respondents which include personal information such as gender, program of study, MUET result and CGPA. The second section B gauges the respondents' level of English Language Self Efficacy. For this purpose, a total of 32 items were adapted from Wang's (2004) original study. Modifications were made on some wordings to suit the local contexts and that presentation of items was arranged by the four English language skills: listening, speaking, reading and writing. It is important to group the items by language skills since each group provides the researcher pertinent information on the level of self-efficacy belief according to the different language skills. Finally, the third section C delves into the English Language Learning Strategies. Fully adopted from Oxford's (1989) work, no changes were made on all 50 items representing six categories of learning strategies namely memory, cognitive, compensation, metacognitive, affective and social strategies.

Prior to the actual study, the questionnaire has been pilot tested whereby the overall Alpha Cronbach value for the instrument was found to be as follows:

Table 1. Reliability Analysis of English Self-Efficacy

\begin{tabular}{lll}
\hline Dimensions & Cronbach's Alpha & N of Items \\
\hline Self-Efficacy for Listening & .790 & 8 \\
\hline Self-Efficacy for Speaking & .852 & 8 \\
\hline Self-Efficacy for Reading & .906 & 8 \\
\hline Self-Efficacy for Writing & .915 & 8 \\
\hline Overall Score & .951 & $\mathbf{3 2}$ \\
\hline
\end{tabular}

From the scores shown in the table, all dimensions scored $>.7$ for Cronbach's alpha value with the highest score of .915 and .790 the lowest. Hence, all items included in the dimensions are acceptable for the study. 
INTERNATIONAL JOURNAL OF ACADEMIC RESEARCH IN BUSINESS AND SOCIAL SCIENCES

Vol. 9, No. 13, Special Issue: Revolutionizing Education: Challenges, Innovation, Collaboration., 2019, E-ISSN: 2222-6990 @ 2019 HRMARS

Table 2. Reliability Analysis of Language Learning Strategies

\begin{tabular}{lll}
\hline Dimensions & Cronbach's Alpha & N of Items \\
\hline Memory Strategies & .828 & 9 \\
\hline Cognitive Strategies & .844 & 14 \\
\hline Compensation Strategies & .828 & 6 \\
\hline Metacognitive Strategies & .886 & 9 \\
\hline Affective Strategies & .566 & 6 \\
\hline Social Strategies & .808 & 6 \\
\hline
\end{tabular}

All dimensions scored $>.8$ for Cronbach's alpha value which is considered as Good except for only Affective Strategies that only scored .566 which may be interpreted as Poor. With the poor score obtained from the items in the dimension, one of the items in the dimensions will be omitted. The omitted item was item number 43, "I write down my feelings in a language learning diary". After the omission, the value changed to .687 which could be considered as Questionable. Even though the value is not highly-achieved, a focused group study may be used to test the robustness of the result.

\section{Population and Sampling}

The target population of this study were students of Universiti Tenaga Nasional (UNITEN), Sultan Haji Ahmad Shah Campus which is located in Muadzam Shah, Pahang. In total, there were 2965 students on the said campus, all of whom belong to the College of Business Management and Accounting (COBA). The institution was chosen because one of the researchers serves as an academic staff and that the findings of this study is important to help understanding his students better. Using simple random sampling, and as suggested by Krejcie and Morgan (1970), a total of 341 respondents were selected as research sample. 
INTERNATIONAL JOURNAL OF ACADEMIC RESEARCH IN BUSINESS AND SOCIAL SCIENCES

Vol. 9, No. 13, Special Issue: Revolutionizing Education: Challenges, Innovation, Collaboration., 2019, E-ISSN: 2222-6990 @ 2019 HRMARS

\section{Findings}

Out of the 341 respondents, there were more females (186; 54.5\%) than males (155; 45.5\%), respectively. Age-wise and other demographic profile can be summarized as follows:

Table 3. Demographic Profile of the Respondents

\begin{tabular}{|c|c|c|c|}
\hline & Item & Frequency & Percentage (\%) \\
\hline \multirow[t]{3}{*}{ Gender } & Male & 155 & 45.5 \\
\hline & Female & 186 & 54.5 \\
\hline & Total & 341 & 100.0 \\
\hline \multirow[t]{6}{*}{ Age } & $18-19$ & 49 & 14.4 \\
\hline & $20-21$ & 152 & 44.6 \\
\hline & $22-23$ & 119 & 34.9 \\
\hline & $24-25$ & 20 & 5.9 \\
\hline & $26-27$ & 1 & .3 \\
\hline & Total & 341 & 100.0 \\
\hline \multirow[t]{6}{*}{ Programme } & Accounting & 125 & 36.7 \\
\hline & Finance & 65 & 19.1 \\
\hline & Marketing & 35 & 10.3 \\
\hline & Human Resource & 88 & 25.8 \\
\hline & International Business & 28 & 8.2 \\
\hline & Total & 341 & 100.0 \\
\hline \multirow[t]{5}{*}{ Year } & 1 & 128 & 37.5 \\
\hline & 2 & 104 & 30.5 \\
\hline & 3 & 79 & 23.2 \\
\hline & 4 & 30 & 8.8 \\
\hline & Total & 341 & 100.0 \\
\hline \multirow[t]{7}{*}{ MUET Result } & Band 1 & 10 & 2.9 \\
\hline & Band 2 & 53 & 15.5 \\
\hline & Band 3 & 141 & 41.3 \\
\hline & Band 4 & 114 & 33.4 \\
\hline & Band 5 & 23 & 6.7 \\
\hline & Band 6 & 0 & 0 \\
\hline & Total & 341 & 100.0 \\
\hline \multirow[t]{5}{*}{ CGPA } & 3.50 and above & 146 & 42.8 \\
\hline & $3.00-3.49$ & 126 & 37.0 \\
\hline & $2.00-2.99$ & 63 & 18.5 \\
\hline & 1.99 and below & 6 & 1.8 \\
\hline & Total & 341 & 100.0 \\
\hline
\end{tabular}


INTERNATIONAL JOURNAL OF ACADEMIC RESEARCH IN BUSINESS AND SOCIAL SCIENCES

Vol. 9, No. 13, Special Issue: Revolutionizing Education: Challenges, Innovation, Collaboration., 2019, E-ISSN: 2222-6990 @ 2019 HRMARS

\section{Level of English Language Proficiency among UNITEN Students}

Table 4. UNITEN Students' MUET Result by Percentage

\begin{tabular}{ccc}
\hline MUET Result & Frequency & Percentage (\%) \\
\hline Band 1 & 10 & 2.9 \\
\hline Band 2 & 53 & 15.5 \\
\hline Band 3 & 141 & 41.3 \\
\hline Band 4 & 114 & 33.4 \\
\hline Band 5 & 23 & 6.7 \\
\hline Band 6 & 0 & 0 \\
\hline Total & 341 & 100.0
\end{tabular}

MUET Result Indicator: Band 6 (Excellent user), Band 5 (Very good user), Band 4 (Good user), Band 3 (Modest user), Band 2 (Limited user), Band 1 (extremely limited user)

Majority of the respondents ( $n=141 ; 41.3 \%)$ were reported to score Band 3 in their Malaysian University English Test (MUET). This shows that most of UNITEN students are modest users of English language. Meanwhile 114 (33.4\%) with Band 4 indicated the students are good users, followed by the third highest percentage from Band $2(n=53 ; 15.5 \%)$ reported to be limited users. 23 respondents (6.7\%) with Band 5 are grouped as very good users and 10 respondents (2.9\%) with Band 1 are extremely limited users. From the survey, there was no student scored Band 6 in MUET who could be categorised as excellent user of English language.

Table 5. Mean Score of UNITEN Students' MUET Result

\begin{tabular}{cccccc}
\hline & $\mathrm{N}$ & Minimum & Maximum & Mean & $\begin{array}{c}\text { Std. } \\
\text { Deviation }\end{array}$ \\
\hline MUET Result & 341 & 1.00 & 5.00 & 3.26 & .902 \\
\hline Valid N (listwise) & 341 & & & & \\
\hline
\end{tabular}

MUET Result Indicator: Band 6 (Excellent user), Band 5 (Very good user), Band 4 (Good user), Band 3 (Modest user), Band 2 (Limited user), Band 1 (extremely limited user)

The above table shows the mean score for UNITEN students' MUET result in which it is found that the average score for the test is 3.25 ( $S D=.902$ ). From the figure, it can be implied that UNITEN students are moderate users of English language.

\section{Respondents' Self-Efficacy Beliefs}

The following shows the level of UNITEN students' self-efficacy belief which are categorized into four major language skills which are listening, speaking, reading and writing. 
INTERNATIONAL JOURNAL OF ACADEMIC RESEARCH IN BUSINESS AND SOCIAL SCIENCES

Vol. 9, No. 13, Special Issue: Revolutionizing Education: Challenges, Innovation, Collaboration., 2019, E-ISSN: 2222-6990 @ 2019 HRMARS

Table 6. UNITEN Students' Self-Efficacy Beliefs by Language Skills

\begin{tabular}{cll}
\hline \multicolumn{1}{c}{ Dimensions } & Mean & Std. Deviation \\
\hline Self-Efficacy for Listening & 3.93 & .643 \\
Self-Efficacy for Speaking & 3.73 & .628 \\
Self-Efficacy for Reading & 3.75 & .606 \\
Self-Efficacy for Writing & 3.65 & .698 \\
\hline Mean score indicator: 1.00-2.33 (Low), 2.34-3.67 (Moderate), 3.68-5.00 (High)
\end{tabular}

The result shows that UNITEN students have high self-efficacy beliefs in three dimensions of the English Language, namely listening, reading and speaking, but they have only moderate self-efficacy belief in writing. Meanwhile, the overall self-efficacy beliefs is 3.77 (SD=.569) which can be interpreted as "high". This occurrence is predictable because in writing, students are expected to bind to grammar rules which could be disturbing to students and eventually affect their self-efficacy beliefs. On the other hand, other language skills do not require them to be fully observant towards the grammar aspect hence allowing them to be more comfortable and confident when using the language.

The Most Used Language Learning Strategy Practiced by UNITEN Students

Table 7. UNITEN Students' Language Learning Strategies

\begin{tabular}{lcc}
\hline \multicolumn{1}{c}{ Dimensions } & Mean & Std. Deviation \\
\hline Memory Strategy & 3.52 & .568 \\
Cognitive Strategy & 3.66 & .586 \\
Compensation Strategy & 3.58 & .652 \\
Metacognitive Strategy & 3.85 & .652 \\
Affective Strategy & 3.64 & .626 \\
Social Strategy & 3.77 & .652 \\
\hline
\end{tabular}

Table 7 displays the mean score for six language strategies. From the score, it is found that most of the respondents applied metacognitive strategy in their language learning $(\mathrm{M}=3.85, \mathrm{SD}=.652)$, followed by social $(M=3.77, S D=.652)$ and cognitive $(M=3.66, S D=.586)$ strategies, respectively. The remaining three strategies, though being employed by a number of students, appeared less popular. The finding is similar to Salahshour, et. al's (2013) study in which they also reported in their study that metacognitive strategies were frequently used by a group of Iranian high school students. Metacognitive strategy according to Oxford (1990) ranges from identifying learner's own learning preference, planning and gathering materials until the evaluation process by the learners themselves, which reflect self-regulated learning from the language learners. 
INTERNATIONAL JOURNAL OF ACADEMIC RESEARCH IN BUSINESS AND SOCIAL SCIENCES

Vol. 9, No. 13, Special Issue: Revolutionizing Education: Challenges, Innovation, Collaboration., 2019, E-ISSN: 2222-6990 @ 2019 HRMARS

\section{Relationship between Self-Efficacy Belief and Students' English Language Proficiency}

Table 8. Relationship between Self-Efficacy Belief and Students' English Language Proficiency

\begin{tabular}{llc}
\hline English Language Self-Efficacy & & MUET Result \\
\hline \multirow{3}{*}{ Self-Efficacy for Listening } & Pearson Correlation & $.376^{* *}$ \\
& Sig. (2-tailed) & .000 \\
& $\mathrm{~N}$ & 341 \\
Self-Efficacy for Speaking & Pearson Correlation & $.321^{* *}$ \\
& Sig. (2-tailed) & .000 \\
Self-Efficacy for Reading & $\mathrm{N}$ & 341 \\
& Pearson Correlation & $.274^{* *}$ \\
& Sig. (2-tailed) & .000 \\
Self-Efficacy for Writing & $\mathrm{N}$ & 341 \\
& Pearson Correlation & $.327^{* *}$ \\
& Sig. (2-tailed) & .000 \\
\hline
\end{tabular}

**. Correlation is significant at the 0.01 level (2-tailed).

The relationship between self-efficacy for all language skills and students' English language proficiency were reported significant with $p<0.01$. Moreover, the values of correlation coefficient, $r=.376$ for listening, $r=.321$ for speaking, $r=274$ and $r=.327$ for reading and writing respectively fall under coefficient range \pm 0.21 to \pm 0.40 which indicated small but a definite relationship between selfefficacy beliefs in all the four skills and English language proficiency as depicted in MUET results. The direction of the relationship is also reported positive, which means if students' self-efficacy beliefs increase, students' English language proficiency would also increase. This finding is akin to the one found by Mahyuddin, et. al's (2006) where they also reported that 1146 Malaysian in their study displayed significant correlation between students' self-efficacy beliefs and English language proficiency.

\section{Relationship between Language Learning Strategies and Students' English Language Proficiency}

Table 9. Relationship between Language Learning Strategies and Students' English Language

\begin{tabular}{llc} 
& \multicolumn{1}{c}{ Proficiency } & \\
\hline Language Learning Strategy & \multicolumn{1}{c}{ MUET Result } \\
\hline \multirow{3}{*}{ Memory Strategy } & Pearson Correlation & $.159^{* *}$ \\
& Sig. (2-tailed) & .003 \\
& $\mathrm{~N}$ & 341 \\
Cognitive Strategy & Pearson Correlation & $.259^{* *}$ \\
& Sig. (2-tailed) & .000 \\
Compensation Strategy & $\mathrm{N}$ & 341 \\
& Pearson Correlation & $.191^{* *}$ \\
& Sig. (2-tailed) & .000
\end{tabular}




\begin{tabular}{llc}
\hline & N & 341 \\
Metacognitive Strategy & Pearson Correlation & $.156^{* *}$ \\
& Sig. (2-tailed) & .004 \\
& $N$ & 341 \\
Affective Strategy & Pearson Correlation & .108 \\
& Sig. (2-tailed) & .047 \\
Social Strategy & $\mathrm{N}$ & 341 \\
& Pearson Correlation & $.152^{* *}$ \\
& Sig. (2-tailed) & .005 \\
\hline
\end{tabular}

**. Correlation is significant at the 0.01 level (2-tailed).

All language learning strategies were reported having significant relationship with students' English language proficiency with $p<0.01$, except for affective strategy with $p>0.01$ that implies no significant relationship. Memory ( $r=1.59)$, compensation ( $r=.191)$, metacognitive ( $r=.156)$, affective $(r=.108)$ and social ( $r=.152$ ) strategies are within coefficient range \pm 0.00 to \pm 0.2 which inferred slight relationship with students' English language proficiency. Cognitive strategy, on the other hand, has small yet definite relationship with students' English language proficiency with $r=.259$. The directions of the five relationships are positive which implies if the language learning strategies increase, the students' English language proficiency, as portrayed in MUET results would also increase. Previous researches (Politzer \& McGroarty, 1985; Abraham \& Vann, 1987; O'Malley \& Chamot, 1990) revealed that successful English language learners tend to adopt language learning strategies compared to those who are less successful. However, there is no concrete finding available to support affective strategy that has no relationship with English language proficiency. The definition of affective strategy may need to be extensively defined to avoid confusion to the respondents in the future.

\section{Conclusion}

This study aims to examine the relationship between UNITEN students' self-efficacy beliefs and language learning strategies on English language proficiency. The findings of the study are as follow:

i. The UNITEN students' English language proficiency is acquired from their Malaysian University English Test (MUET). The average score for the result was Band 3 that implies modest users of the English language.

ii. UNITEN students have high self-efficacy in listening, reading and speaking, but moderate selfefficacy in writing. However, the overall self-efficacy as in the mean score of the computed variables; the mean sores of self-efficacy for listening, speaking, reading and writing is reported high.

iii. The most frequently used language learning strategy practiced by UNITEN students was metacognitive strategy followed by social strategy, cognitive strategy, affective strategy, compensation strategy and memory strategy as the least used learning strategy.

iv. There was a small but definite relationship between self-efficacy beliefs in all the four language skills and English language proficiency (as depicted in MUET results). 
INTERNATIONAL JOURNAL OF ACADEMIC RESEARCH IN BUSINESS AND SOCIAL SCIENCES

Vol. 9, No. 13, Special Issue: Revolutionizing Education: Challenges, Innovation, Collaboration., 2019, E-ISSN: 2222-6990 @ 2019 HRMARS

v. Memory, cognitive, compensation, metacognitive and social language learning strategies reported having slight relationship with students' English language proficiency. However, affective language learning strategy indicated no relationship with the proficiency.

Despite the positive findings, the study is only limited to UNITEN context, hence they do not represent other students in other local institutions. It is hoped that future researchers could replicate the study on a larger sample in other higher learning institutions. The research could also be conducted using qualitative method in order to get in-depth results from the respondents. With the current findings, English language instructors are expected to be more conscious of students' level of self-efficacy in English language classroom, whereas English language learners also need to be more selective in adopting proper language learning strategy that can help them boost their self-efficacy in learning the target language.

\section{References}

Abraham, R. \& Vann, R. (1987). Strategies of two learners: A case study. In A. L. Wenden \& J. Rubin (Eds.), Learner Strategies in Language Learning (pp. 85-102). New York: Prentice Hall.

Bandura, A. (1994). Self-efficacy. In V. S. Ramachaudran (Ed.), Encyclopedia of human behavior (Vol. 4, pp. 71-81). New York: Academic Press.

Bandura, A. (2006). Guide for constructing self-efficacy scales. In F. Pajares \& T. Urdan (Eds.). Selfefficacy beliefs of adolescents, (Vol. 5., pp. 307-337). Greenwich, CT: Information Age Publishing.

EF English Proficiency Index. (2017). Education First. Retrieved from https://www.ef.com/epi/regions/asia/malaysia/

Subramaniam, G. (2003). Literature Programmes in Malaysian Schools: A Historical

Overview. In Ganakumaran Subramaniam, \& M. E. Vethamani (Eds.), Teaching of Literature in ESL/EFL Contexts (pp. 27-48). Petaling Jaya: Sasbadi.

Hazlina, A. (2016, September 28). Raising English language proficiency, News Straits Times.

Retrieved from https://www.nst.com.my/news/2016/09/176566/raising-english-languageproficiency

Kim, J. \& Lorsbach, A. W. (2005). Writing self-efficacy in young children: Issues for the early grade environment. Learning Environments Research, 8, 157-175.

Mahyuddin, R. Elias, H., Cheong, L., Muhammad, M., Noordin, N. \& Abdullah, M. (2006). The Relationship Between Students' Self-efficacy and Their Achievement. Jurnal Pendidik dan Pendidikan, Jil. 21, 61-71.

Making Jobles Grad Employable. (2016). The Star Online. Retrieved from https://www.thestar.com.my/news/education/2016/03/13/making-jobless-gradsemployable/

Muelas, A. \& Navarro, E. (2015). Learning Strategies and Academic Achievement. Procedia-Social and Behavioral Sciences, 165, 217-221.

Rahman, N. A. A., \& Mahir, N. A. (2008). Communication Apprehension in a Language Classroom. In H. Harun (Ed.), Issues on English As Second Language Pedagogy: A Research based Perspective (pp. 1-18). Bandar Baru Nilai: Universiti Sains Islam Malaysia.

O’Malley, J. M. \& Chamot, A. U. (199). Learning strategies in second language acquisition. Cambridge, 
INTERNATIONAL JOURNAL OF ACADEMIC RESEARCH IN BUSINESS AND SOCIAL SCIENCES

Vol. 9, No. 13, Special Issue: Revolutionizing Education: Challenges, Innovation, Collaboration., 2019, E-ISSN: 2222-6990 @ 2019 HRMARS

England: Cambridge University Press.

Oxford, R. (1989). Language Learning Strategies: What Teacher Should Know. New York. Newbury House.

Politzer, R. L. \& McGroarty, M. (1985). An exploratory study of learning behaviors and their relationship to gain in linguistic and communicate competence. TESOL Quarterly, 21 (1), 87 111.

Saeid, R., Tan, B. H. \& Chan, S. H. (2012). Self-efficacy in Second/Foreign Language Learning Contexts. English Language Teaching, 5, 60-73.

Salahshour, F., Sharifi, M. \& Salahshour, N. (2013). The Relationship between Language Learning Strategy Use, Language Proficiency Level and Learner Gender. Procedia-Social and Behavioral Sciences, 70, 634-643.

Scarcella, R. \& Oxford, R. (1992). The Tapestry of Language Learning: The Individual in the Communicative Classroom. Boston: Heinle \& Heinle.

Shyr, Wen-Jye, F., Hung-Yun \& Zeng, Li-Wen, Hsieh, Ying-Ming \& Shih, Chia-Yu. (2017). The Relationship between Language Learning Strategies and Achievement Goal Orientations from Taiwanese Engineering Students in EFL Learning. Eurasia Journal of Mathematics, Science and Technology Education, 13(10), 6431-6443.

Uslu, M. E., Sahin, E. \& Odemis, I. S. (2016). The Effect of Language Learning Strategies and Academic Achievement. Journal of Educational and Instructional Studies In The World, 6(3), 73-78.

Wang, C. (2004). Chinese college students' self-regulated learning strategies and self-efficacy beliefs in learning English as a foreign language. TESOL Quarterly.

Werden, A. L. \& Rubin, J. (Eds.). (1987). Learner strategies in language learning. Cambridge: Prentice Hall.

Wong, M. S. (2005). Language Learning Strategies and Language Self-Efficacy. RELC Journal, 36(3), 245-296.

Woodrow, L. (2005). The Challenge of Measuring Language Learning Strategies. Foreign Language Annals, 38(1), 90-99.

Zimmerman, B. J. \& Pons, M. M. (1986). Development of a structured interview for assessing student use of self-regulated learning strategies. American Educational Research Journal, 23, 614-628. 